French, E. L. \& AdA, G. L. (1959). J. gen. Microbiol. 21, 550-560

\title{
Stimulation of the Production of Neuraminidase in Vibrio cholerae Cultures by $\boldsymbol{N}$-Acetylneuraminic Acid and Sialyl-Lactose
}

\author{
BY E. L. FRENCH* AND G. L. ADA \\ The Walter and Eliza Hall Institute of Medical Research, Royal Melbourne \\ Hospital Post Office, Victoria, Australia
}

\begin{abstract}
SUMMARY: A simple medium is described which allows adequate growth of Vibrio cholerae with the production of only trace amounts of neuraminidase. When added to this medium to give a final concentration of $600 \mu \mathrm{M}$, sialyl lactose or sialyl- $N$-: acetylgalactosamine, two oligosaccharides which contain ketosidically bound $\mathrm{N}$-acetylneuraminic acid and which are substrates of neuraminidase, caused at least a 100-fold increase in the amount of neuraminidase produced during growth of the organisms. $N$-Acetylneuraminic acid was also found to stimulate neuraminidase production. Galactose and $N$-acetylgalactosamine had no effect. $N$-Acetylneuraminic acid was metabolized by $V$. cholerae as indicated by the disappearance from such enriched medium of substances giving the direct Ehrlich reaction. Evidence is presented which suggests that neuraminidase is an extracellular enzyme.
\end{abstract}

McCrea (see Burnet, McCrea \& Stone, 1946; McCrea, 1947) first observed the presence in partially purified preparations of Clostridium welchii toxin type $\mathbf{A}$ of a factor able to inactivate the influenza virus receptors of human red cells, thus preventing agglutination of the cells by the virus. Culture fluids of Vibrio cholerae were soon found to be a richer source of the factor, which was recognized as an enzyme and referred to as the receptor-destroying enzyme (RDE; Burnet \& Stone, 1947). Chemical evidence for the activity of RDE was presented by Gottschalk \& Lind (1949). The glycosidase nature of the enzyme was established by Gottschalk (1956) and shortly afterwards by Heimer \& Meyer (1956). When presenting evidence for the $O$-glycosidic type of the linkage susceptible to RDE, Gottschalk (1957) termed the enzyme neuraminidase and defined its action as 'the hydrolytic cleavage of the glycosidic bond joining the keto groups of neuraminic acid to D-galactose or D-galactosamine and possibly to other sugars'. The enzyme is also called sialidase(Heimer \& Meyer, 1956).

Shortly after its discovery, a method for the purification of the RDE enzyme was described (Ada \& French, 1950). We were unable to achieve a high degree of purification of the enzyme at that time, owing to the complex nature of the culture medium (nutrient sloppy agar) and the low enzyme titres obtained. This laboratory has since been engaged in a search for factors which, when added to a simple culture medium, would result in an improved yield of neuraminidase. Such factors have been found to be present in several biological preparations, and particularly in bovine colostrum. A preliminary

* Present address: Division of Animal Health and Production, C.S.I.R.o., Animal Health Research Laboratory, Parkville, Victoria, Australia. 
examination (Ada \& French, 1957) of the substance isolated from bovine colostrum indicated that it had properties similar to those of lactaminic acid-lactose ( $N$-acetylneuraminyl-lactose) described by Kuhn \& Brossmer (1956).

In the present paper, a simple medium is described which allows adequate growth of Vibrio cholerae and provides conditions in which the neuraminidase produced is not destroyed. When added to this medium $N$-acetylneuraminic acid ( $N$-ANA) and two oligosaccharides containing ketosidically bound $N$-ANA have been found to stimulate production of neuraminidase by this organism.

\section{METHODS}

Vibrio cholerae. The $4 \mathrm{Z}$ strain of Vibrio cholerae used is an old laboratory strain kindly supplied in 1946 to the Hall Institute by Professor S. D. Rubbo of the Bacteriology Department, University of Melbourne. It grows readily in nutrient broth, peptone water and on nutrient agar; large smooth colonies with clear haemolysis are produced on horse blood agar. It has been maintained as a lyophilized stock. The working stock is subcultured weekly on nutrient agar which, after overnight incubation at $37^{\circ}$, is stored at $4^{\circ}$ between subcultures.

Viable counts of Vibrio cholerae. Serial tenfold dilutions.. were made in nutrient broth in an ice bath and four $0.05 \mathrm{ml}$. quantities of suitable dilutions allowed to dry on the surface of horse blood agar plates. Counts were made of typical colonies which developed after incubation for $48 \mathrm{hrs}$.

Titration of neuraminidase activity. An initial dilution, corresponding to the minimum value of the suspected order of magnitude of the titre, was. made in calcium acetate. saline, using analytical pipettes and flasks. Two sets of doubling dilutions of the initial dilution were made in the same diluent, one beginning undiluted and the other $1 / 3$ so that the whole range of dilutions were undiluted, $1 / 2,1 / 3,1 / 4,1 / 6, \ldots, 1 / 96$. To one volume $(0.25 \mathrm{ml}$.) of each dilution (held in tubes $75 \mathrm{~mm}$. $\times 12 \mathrm{~mm}$.) was added an equal volume of $1 \%(\mathrm{v} / \mathrm{v})$ washed fowl red cells in physiological saline, and the mixture incubated in a water bath at $37^{\circ}$ for $60 \mathrm{~min}$. The tubes were then well shaken and $0.25 \mathrm{ml}$. citrate saline containing 5 agglutinating doses of MEL influenza virus added. After mixing (by shaking) the red cells were allowed to settle at room temperature for $45 \mathrm{~min}$. The dilution which showed the standard 'one plus' degree of haemagglutination was taken as the end-point. $\mathbf{A}$ ' standard enzyme preparation was included in most tests.

Influenza virus. The Melbourne strain MEL $M$, described by Isaacs \& Edney (1950), was grown from limit dilution in the allantoic cavity of 11-day fertile hen eggs. Allantoic fluid virus was mixed with an equal volume of sterile glycerol. When stored at $-20^{\circ}$, this preparation remained stable (as haemagglutinin) for at least 12 months.

Physiological saline was $\mathrm{NaCl} 0.85 \mathrm{~g} . / 100 \mathrm{ml}$. distilled water.

Calcium acetate saline was prepared as follows. $\mathrm{NaCl}, 5 \cdot 0 \mathrm{~g}$.; $\mathrm{CaCl}_{2}, \mathbf{1 . 0} \mathrm{g}$.; $\mathrm{CH}_{3} \mathrm{COONa}, 12 \cdot 3 \mathrm{~g}$; $\mathrm{N}-\mathrm{CH}_{3} \mathrm{COOH}, 2 \cdot 6 \mathrm{ml}$; made up to $1 \mathrm{l}$. with distilled water. 
After autoclaving (15 lb./sq.in.; $20 \mathrm{~min}$.), the cooled solution had a $\mathrm{pH}$ value of $6 \cdot 2$.

Citrate saline was physiological saline containing also sodium citrate $2 \mathrm{~g} . / 100 \mathrm{ml}$. saline.

Collidine. A commercial preparation of $\gamma$-collidine (2:4:6-trimethylpyridine) was redistilled before use.

Determination of $\mathrm{pH}$ values. Where there was a sufficient volume ( $\$ 2 \mathrm{ml}$.) determinations were carried out with a glass electrode. The majority of estimations were carried out on less than $0.05 \mathrm{ml}$., with indicator papers.

Ion exchange resins. Resins $1 \mathrm{R}-120$ and $1 \mathrm{R}-4 \mathrm{~B}$ were products of the Rohm Haas Co. Resin 1R-120 was regenerated with $2 \mathrm{~N}-\mathrm{HCl}$. Resin $\mathbf{1 R - 4 B}$ was regenerated with $2 \mathrm{~N}-\mathrm{NH}_{4} \mathrm{OH}$. Resin Dowex 1 was a product of the Dow Chemical Co.; it was well washed with $2 \mathrm{~N}-\mathrm{HCl}$ and $2 \mathrm{~N}-\mathrm{NaOH}$ before use and was used in the formate form.

Estimation of sialic acid (N-acetylneuraminic acid; $N$-ANA). $N$-ANA was estimated by the direct Ehrlich reaction as described by Werner \& Odin (1952). Crystalline $N$-ANA isolated from sialyl lactose (see below) was used as the standard reference compound.

Estimation of N-acetylhexosamine. The Morgan \& Elson method (1934) as modified by Reissig, Strominger \& Leloir (1955) was used. Crystalline $\mathrm{N}$-acetylglucosamine, prepared from $\mathrm{D}$-glucosamine $\mathrm{HCl}$ by the method of Breuer (1898) was used as the standard reference compound.

Paper chromatography solvents. Descending chromatography was carried out using Whatman no. 1 paper. The two solvent systems employed were $n$-butanol, pyridine and water $(6+4+3)$ (Gottschalk, 1955); and $n$-butanol, pyridine, dimethyl formamide and water $(2+1+1+1)$.

Paper chromatography sprays. Aniline hydrogen phthalate(Partridge, 1949); benzidine + trichloroacetate (Bacon \& Edelman, 1951) and cresol green.

\section{Isolation and identification of active factors}

Sialyl lactose. Unless otherwise stated, all procedures -were carried out at $0-4^{\circ}$. Ten litres of bovine colostrum (preferably first milking after parturition) were dialysed for 4-14 days against 3 vol. distilled water previously saturated with $\mathrm{CHCl}_{3}$. The dialysate was adjusted to $c . \mathrm{pH} 8.5$ with saturated $\mathrm{Ba}(\mathrm{OH})_{2}$ solution, and the flocculent precipitate allowed to settle for $c .1 \mathrm{hr}$. The supernatant fluid, obtained by decantation and centrifugation, was stirred with $50 \mathrm{~g}$. resin $1 \mathrm{R}-120$ until the $\mathrm{pH}$ value fell to $c$. 6. The solution was passed through columns $(45 \mathrm{~cm} . \times 2.5 \mathrm{~cm}$.) of resins $1 R-120$ and $1 R-4 B$ and then through a column $(17 \mathrm{~cm} . \times 2 \mathrm{~cm}$.) of Dowex 1 . The latter column was washed with $200 \mathrm{ml}$. water and then developed with $2 \mathrm{~N}-\mathrm{HCOOH}$. The effluent was collected in $4 \mathrm{ml}$. fractions, and the fractions tested with Ehrlich's reagent. The fluids which gave a positive reaction were pooled and dried in vacuo from the frozen state. The dried substance was dissolved in a minimum amount of methanol (insoluble material being discarded) and excess acetone added to the solution. The flocculent precipitate was washed once with acetone + methanol 
$(9: 1)$ and dissolved again in methanol. After removal of insoluble material, excess diethyl ether.was added to the solution and the resulting precipitate thrice washed with di : ethyl ether. Nitrogen was passed over the precipitate to remove the ether and the material finally dried to constant weight (room temperature) in a desiccator. The yield was very variable; in one experiment 3 g. was obtained.

Paper chromatography in butanol + pyridine + water gave one spot of $\boldsymbol{R}_{\mathrm{F}}=\mathbf{0 . 0 4}$ (lactose $\boldsymbol{R}_{\mathrm{F}}=\mathbf{0} \cdot 10$ ); in butanol + pyridine + dimethyl formamide + water, one spot of $R_{\mathrm{F}}=0.37$ (lactose $\boldsymbol{R}_{\mathrm{F}}=0 \cdot 42$ ).

Purified bacterial neuraminidase and influenza virus quantitatively split this substance into lactose and a substance reacting in the direct Ehrlich reaction (see Ada \& French, 1957). The lactose moiety was identified by acid digestion $\left(0.25 \mathrm{~N}-\mathrm{H}_{2} \mathrm{SO}_{4}, 16 \mathrm{hr}\right.$., $\left.100^{\circ}\right)$ yielding equal amounts of glucose and galactose (Ada \& French, 1957).

Crystalline $N$-ANA was obtained from sialyl lactose as follows : $500 \mathrm{mg}$. was dissolved in $3 \mathrm{ml}$. water and heated at $80^{\circ}$ for $40 \mathrm{~min}$. The solution was passed through a Dowex 1 column $(12 \mathrm{~cm} . \times 2 \mathrm{~cm}$.) which was then well washed with water. The column was developed with $2 \mathrm{~N}-\mathrm{HCOOH}$, the eluate being collected in $4 \mathrm{ml}$. fractions. Those fractions which gave a positive reaction with Ehrlich's reagent was pooled and dried in vacuo from the frozen state, yielding a white fluffy powder. This material was crystallized and recrystallized by the method of Kuhn \& Brossmer (1956). The crystals were dried to constant weight at $80^{\circ}$ over $\mathrm{KOH}$ and $\mathrm{P}_{2} \mathrm{O}_{5}$.

Elementary analysis. Calc.: $\mathrm{C}=42.7 ; \mathrm{H}=6.19 ; \mathrm{N}=4.53$. Found $\mathrm{C}=42 \cdot 4, \mathrm{H}=6 \cdot 23, \mathrm{~N}=4 \cdot 34$.

Sialyl galactosamine (6- $\alpha$-D- $N$-acetylneuraminyl- $N$-acetylgalactosamine) was isolated from bovine submaxillary glands by Gottschalk \& Graham (1958); a sample was kindly provided by Dr Gottschalk.

Basal culture medium. In order to study the stimulating effect of the different compounds on neuraminidase production, the elaboration of a defined basal medium supporting bacterial growth without formation of neuraminidase in appreciable amounts was necessary. A further requirement was that neuraminidase produced in such a medium, containing an added active compound, should be stable. After many trials, the medium described in Table 1 was found to be satisfactory. It is a modification of that described by Feldman (1958), who in turn modified the original medium of. Finkelstein \& Lankford (1955). The medium had the further advantage of not interfering in the method used for the determination of $N$-ANA, $N$-acetylhexosamine and hexosamine. It also avoided the use of high concentrations of inorganic salts which had been found (French \& Ada, unpublished) seriously to interfere with the yield of neuraminidase.

The medium was made up as follows. The collidine $+\mathrm{HCl}$ solution was made up to give a solution ten times the required final strength. This solution was sterilized by Seitz filtration. The remaining components were dissolved in water to give a solution twice the required final concentration. This solution was sterilized by autoclaving (15 lb./sq. in.; $20 \mathrm{~min}$.). Appropriate volumes of the 
two solutions were then mixed. The complete medium (subsequently referred to as GGC medium) was stored at $2^{\circ}$ for periods up to 3 months or for longer periods at $-20^{\circ}$.

Experimental procedure. All samples to be tested for their ability to stimulate neuraminidase production were neutralized to $\mathrm{pH}$ 6.5-7:0 with $\mathrm{NaOH}$ and heated to $56^{\circ}$ for $30 \mathrm{~min}$. before addition to the basal medium. The medium to be inoculated was held in tubes $(2-4 \mathrm{ml}$. in $1.8 \times 15 \mathrm{~cm}$. tubes; $5-10 \mathrm{ml}$. in $2.5 \times 15 \mathrm{~cm}$. tubes) which were rocked (amplitude $2.5 \mathrm{~cm}$., 120 oscillations/ min.) in a bath held at $37^{\circ}$. The medium was inoculated (at the rate of $0.05 \mathrm{ml} . /$ $2.0 \mathrm{ml}$. medium) with a broth culture (incubated at $37^{\circ}$ ) which in turn had

Table 1. Composition of basal culture medium for Vibrio cholerae strain $4 \mathrm{Z}$

\begin{tabular}{|c|c|c|c|}
\hline Substance & $\begin{array}{c}\text { Concentration } \\
(\mathrm{mm})\end{array}$ & Substance & $\begin{array}{c}\text { Concentration } \\
(\mathrm{mM})\end{array}$ \\
\hline Glutamic acid & 35 & Ammonium sulphate & 0.6 \\
\hline Glycerol & 100 & Magnesium sulphate & 0.3 \\
\hline Adenine & $\mathbf{0} \cdot \mathbf{3}$ & Collidine & 5 \\
\hline $\begin{array}{l}\text { Dipotassium hydrogen } \\
\text { phosphate }\end{array}$ & 2 & Hydrochloric acid & to $\mathrm{pH} 6.9$ \\
\hline
\end{tabular}

been inoculated from an agar slope $4-5 \mathrm{hr}$. previously. Sampling involved removal of $0.10 \mathrm{ml}$, which was then added to $0.90 \mathrm{ml}$. of a calcium acetate buffer (pH 6.2), containing $10 \%(\mathrm{v} / \mathrm{v})$ broth held in a plastic tube. The tubes were kept at $-20^{\circ}$. until the end of the experiment when one drop of toluene was added to each and the organisms lysed by four rapid cycles of freezing $\left(c .-40^{\circ}\right)$ and thawing (water at $20^{\circ}$ ). The tubes were centrifuged at $2000 \mathrm{~g}$ for $20 \mathrm{~min}$. and the samples for enzyme estimation removed from the supernatant fluids. Two types of experiment were carried out. In the first, samples were taken $16 \mathrm{hr}$. after inoculation. In the second procedure, samples for enzyme estimation were removed at intervals during $12 \mathrm{hr}$. incubation after inoculation.

\section{RESULTS}

\section{Decrease in $\mathrm{pH}$ value of medium during growth of the organisms}

Following inoculation, the $\mathrm{pH}$ value of the medium decreased from 6.9 to about 6.0 after $12-16 \mathrm{hr}$. incubation at $37^{\circ}$. Addition to the medium of the different compounds in the concentrations reported had no effect on this decrease. in $\mathrm{pH}$.value.

\section{Stability of added neuraminidase in the basal medium inoculated reith Vibrio cholerae}

When added to a sample of the medium which had been inoculated with Vibrio cholerae, neuraminidase was found to be stable. Medium containing added sialyl lactose $(600 \mu \mathrm{M})$ was inoculated with $V$. cholerae and incubated for $16 \mathrm{hr}$. at $37^{\circ}$ as above. The culture fluid was centrifuged $(2000 \mathrm{~g}, 20 \mathrm{~min}$.) and the clear supernatant fluid removed. Part of this was heated under conditions 
$\left(80^{\circ}, 30\right.$ min. $)$ known not to affect sialyl lactose but which destroyed neuraminidase. GGC medium to which was added equal volumes of either heated or unheated supernatant fluid was prepared, inoculated and incubated as above. Samples were taken at 0 and $12 \mathrm{hr}$. In medium containing unheated fluid, the enzyme titres were: at $0 \mathrm{hr}$., 800 ; at $12 \mathrm{hr}$., 650 . In medium containing heated fluid the titres were: at $0 \mathrm{hr}$., < 10; at $12 \mathrm{hr}$., 20.

\section{Effect of added compounds on the growth of organisms}

Addition to the basal medium of sialyl lactose, $N$-ANA or lactose to a concentration of $600 \mu \mathrm{M}$ (the concentration used in many of the experiments to be reported) was found to have little or no effect on the growth of the organisms. Control medium and media containing added compounds were inoculated with Vibrio cholerae to give a final concentration of $8.5 \times 10^{5}$ viable organisms $/ \mathrm{ml}$. After $12 \mathrm{hr}$. incubation, the viable count $/ \mathrm{ml}$. in the control medium was $6.5 \times 10^{8}$ organisms; in the medium containing $N$-ANA, 5.0 $\times 10^{8}$; in the medium containing sialyl lactose, $8.0 \times 10^{8}$; and in the medium containing lactose, $10.5 \times 10^{8}$.

\section{Comparison of the effects of sialyl lactose and $\mathrm{N}-A N A$ on neuraminidase production}

Effect of concentration of added compounds. Sialyl lactose and $N$-ANA were found to increase the amounts of enzyme produced when added to the basal medium over the range 80-2400 $\mu \mathrm{M}$. In both cases, the amount of enzyme produced depended upon the concentration of added compound. Details of an experiment in which enzyme titres were estimated $16 \mathrm{hr}$. after inoculation are given in Table 2.

Table 2. Effect of concentration of $\mathrm{N}$-acetylneuraminic acid $(\mathrm{N}-\boldsymbol{A} \boldsymbol{N} A)$ and sialyl lactose on the amount of neuraminidase produced by Vibrio cholerae

\begin{tabular}{|c|}
\hline $\begin{array}{l}\text { Concentration } \\
\text { of N-ANA or } \\
\text { sialyl lactose } \\
\quad(\mu \mathrm{M})\end{array}$ \\
\hline 2400 \\
\hline 800 \\
\hline 240 \\
\hline 80 \\
\hline Nil \\
\hline
\end{tabular}

\begin{tabular}{cc}
\multicolumn{2}{c}{$\begin{array}{c}\text { Enzyme titre in media } \\
\text { containing }\end{array}$} \\
\hline N-ANA & Sialyl lactose \\
1000 & 2800 \\
900 & 1800 \\
400 & 1600 \\
110 & 1600 \\
50 & 60
\end{tabular}

Effect of subculturing Vibrio cholerae in the GGC medium on the amount of neuraminidase produced. When the organisms used for inoculation were subcultured several times in GGC medium instead of broth, the amount of neuraminidase produced after $12 \mathrm{hr}$. growth in the basal medium was very low. In such an experiment, GGC medium or GGC medium containing added sialyl lactose (to $600 \mu \mathrm{M}$ ) were inoculated with organisms subcultured in broth (final concentration $1.8 \times 10^{7}$ viable organisms $/ \mathrm{ml}$.) or with organisms subcultured in GGC medium (final concentration $1 \cdot 1 \times 10^{7}$ viable organisms $/ \mathrm{ml}$.). 
At $11 \mathrm{hr}$. the counts of organisms were $15 \times 10^{8} / \mathrm{ml}$. and $5 \cdot 0 \times 10^{8} / \mathrm{ml}$, respectively. In the tube inoculated with organisms subcultured in broth, the titres at $12 \mathrm{hr}$. were: basal medium, 70; medium + sialyl lactose, 2300. In the tubes inoculated with organisms subcultured in GGC medium, the titres at $12 \mathrm{hr}$. were: basal medium, 10; medium $\times$ sialyl lactose, 1800 .

Rate of production of neuraminidase in the presence of added compounds. $N$-ANA, sialyl lactose or sialyl $N$-AGal were added to separate lots of media to give a final concentration of $600 \mu \mathrm{M}$. Together with a control, the media were inoculated and incubated. The enzyme titres are plotted in Fig. 1.

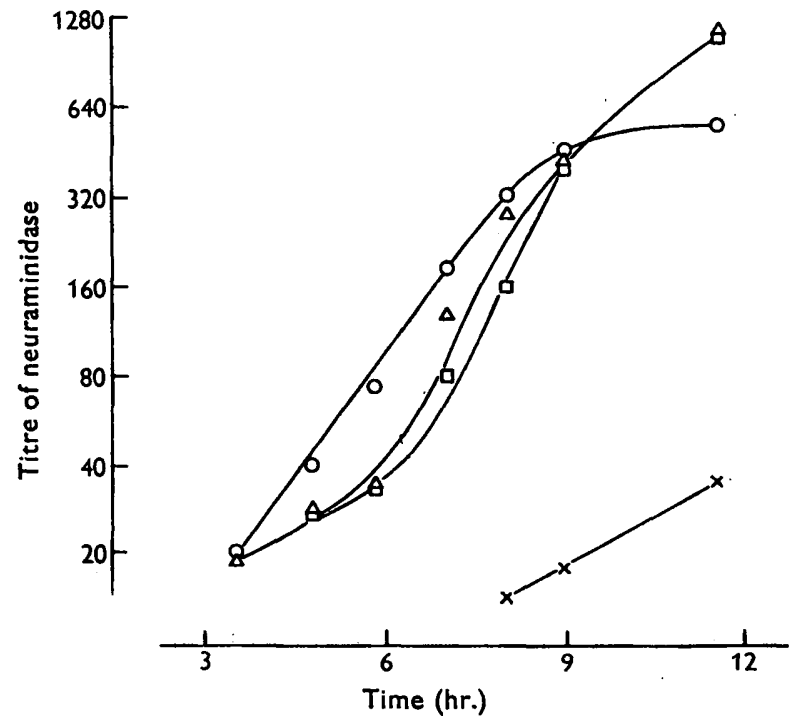

Fig. 1. Rate of production of neuraminidase in the presence of $\mathbf{N}$-acetylneuraminic acid, sialyl lactose and sialyl- $N$-acetylgalactosamine $(600 \mu \mathrm{M})$. Basal medium alone, $x-x$; basal medium $+N$-acetylneuraminic acid, $\mathrm{O}-\mathrm{O}$; basal medium + sialyl lactose, $\Delta-\triangle$; basal medium + sialyl- $N$-acetylgalactosamine, $\square-\square$.

Disappearance of added active factors in media during growth of organism: Media containing either sialyl lactose (to $600 \mu \mathrm{M}$ ), sialic acid (to $600 \mu \mathrm{M}$ ) or no added factor, were inoculated and incubated for $12 \mathrm{hr}$. The direct Ehrlich reaction was used to follow the rate of disappearance of these compounds during growth of the organism. The compounds were found to be stable in uninoculated medium which had been kept for $12 \mathrm{hr}$. at $37^{\circ}$. The results of this experiment are presented in Fig. 2. In the medium to which sialic acid had been added, the amount of sialic acid began to decrease after the 4 th $\mathrm{hr}$. of incubation and had disappeared by the 8-10th hr. Samples removed at later times also gave negative reactions. Sialyl lactose was metabolized more slowly (as indicated by the reaction with Ehrlich's reagent which estimates the sialic acid portion) and some was still present at $12 \mathrm{hr}$. In a separate experiment it was found that all the sialic acid portion of added sialyl lactose had been metabolized by the 24th $\mathrm{hr}$. after inoculation. In this experiment the titre of neuraminidase rose from 1600 at $10 \mathrm{hr}$. to 2300 at $24 \mathrm{hr}$. 
Appearance during the breakdown of N-ANA of a compound reacting in the Morgan \& Elson reaction. Two lots of GGC medium, one containing $N$-ANA (to $600 \mu \mathrm{M}$ ), were inoculated and then incubated at $37^{\circ}$. Samples were taken at intervals and the amount of $N$-ANA (direct Ehrlich reaction) and of compounds reacting in the Morgan \& Elson reaction were determined. The results of one experiment are shown in Fig. 3.

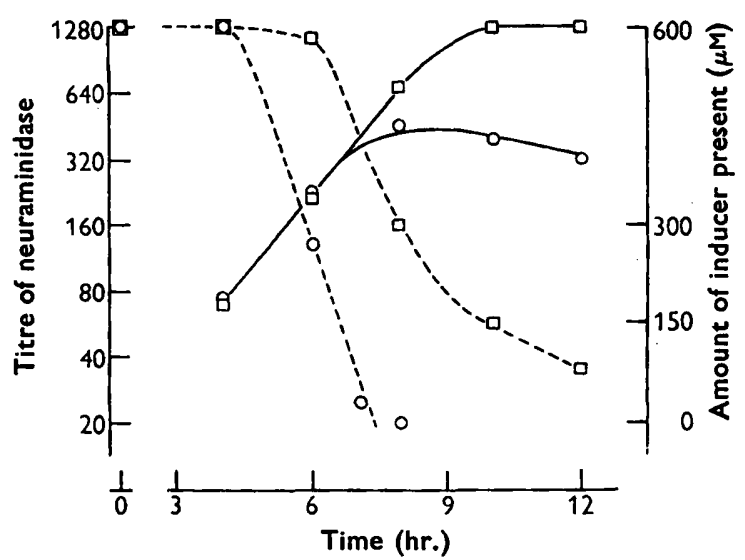

Fig. 2. Rate of production of neuraminidase and the rate of disappearances of added factors (as estimated by the direct Ehrlich test) in media enriched with $\boldsymbol{N}$-acetylneuraminic acid or sialyl lactose. Enzyme production in the presence of $N$-acetylneuraminic acid, $\mathrm{O}-\mathrm{O}$; amount of $\mathrm{N}$-acetylneuraminic acid in medium, $\mathrm{O}-\cdots$ - $\mathrm{O}$; enzyme production in the presence of sialyl lactose, $\square-\square$; amount of sialyl lactose in medium, $\square \cdots \cdots$.

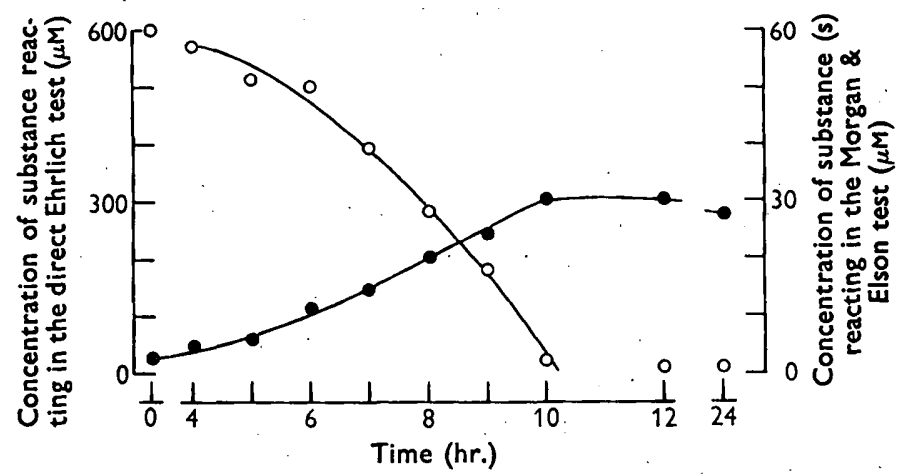

Fig. 3. Disappearance of added $N$-acetylneuraminic acid ( $N$-ANA; as estimated by reaction in the direct Ehrlich test) from medium inoculated with Vibrio cholerae and concomitant appearance in such a culture of material which reacts in the Morgan \& EIson test. Added $\mathrm{N}$-ANA, $\mathrm{O}-\mathrm{O}$; material reacting in the Morgan \& Elson test,

A substance which reacted in the Morgan \& Elson test appeared during the breakdown of $N$-ANA. It was detected in greatest amount at the time when reaction in the direct Ehrlich test had become almost negative (c. $10 \mathrm{hr}$. after inoculation). The maximum amount of this factor was equivalent to a concentration of $30 \mu \mathrm{M} \mathrm{N}$-acetylglucosamine; this result was obtained in four 
experiments. The stability of the substance varied, however, in different experiments. In two experiments the extent of reaction in the Morgan \& Elson test remained almost unchanged between the 10th and 24th hr. In the other two experiments the extent of reaction decreased after $24 \mathrm{hr}$. incubation to $50 \%$ or less of the maximum value reached at $10 \mathrm{hr}$. incubation.

\section{Liberation of neuraminidase from Vibrio cholerae}

At the suggestion of Dr M. R. Pollock, an experiment was carried out to see whether neuraminidase was liberated from the intact bacteria or appeared in solution only on lysis. Medium containing added sialyl lactose $(600 \mu \mathrm{M})$ was inoculated in the usual way and incubated at $37^{\circ}$. At 4, 6 and $7 \mathrm{hr}$., when the medium would be expected to contain mainly viable organisms, $1 \mathrm{ml}$. samples were taken, spun at $10,000 \mathrm{~g}$ for $15 \mathrm{~min}$. and the supernatant fluid removed. The residues were washed with $1 \mathrm{ml}$. medium and finally resuspended in $1 \mathrm{ml}$. medium. The latter was frozen and thawed four times in the presence of toluene, a procedure which was found to disrupt the bacterial cells (as shown in electron micrographs) but not to affect the titre of neuraminidase. The following are the titres of neuraminidase present in the supernatant fluids and washed cells' extracts. At $4 \mathrm{hr}$., supernatant fluid $=40$, organisms $<1$; at $6 \mathrm{hr}$., supernatant fluid $=220$, organisms $<1$; at $7 \mathrm{hr}$., supernatant fluid $=$ 440, organisms $=6$. These results suggest that neuraminidase is an extracellular enzyme.

\section{DISCUSSION}

The evidence presented in this paper indicates clearly that neuraminidase is an inducible rather than a constitutive enzyme in Vibrio cholerae. Organisms which were freed from traces of broth by serial subculture in the GGC medium produced only trace amounts of neuraminidase; thus an enzyme titre of 10 was found after $11 \mathrm{hr}$. incubation. In medium to which sialyl lactose had been added $(600 \mu \mathrm{M})$, the titre at $11 \mathrm{hr}$. was 1800 . Addition of inducers to the medium in this concentration did not affect the growth rate of the organism.

In studies of enzyme induction with other bacterial strains it has been established that substrates or one of the two compounds joined by the enzymesusceptible bond may be active as inducers for the enzyme itself. A wellknown example is the activity of lactose and galactose as inducers for $\beta$-galactosidase in Escherichia coli. Both the substrates of neuraminidase tested in the present investigations, sialyl lactose and sialyl- $\boldsymbol{N}$-AGal, were inducers, and $N$-ANA, which is present in both substrates, was active. Galactose, lactose and galactosamine were inactive. The amount of enzyme produced by the organisms depended upon the concentration of inducer in the medium; this concentration dependence (over the range 2400 to $80 \mu \mathrm{M}$ ) was quite marked in the case of $N$-ANA but was only slight when sialyl lactose was the inducer. This aspect is being further investigated.

Heimer \& Meyer (1956) showed that crude extracts of Vibrio cholerae contained an aldolase which split $N$-ANA into an $N$-acetylhexosamine and pyruvate. We have confirmed that $V$. cholerae can metabolize $N$-ANA. This 
was demonstrated by the disappearance of substances giving the direct Ehrlich reaction from medium containing $N$-ANA and by the appearance of material which reacted in the Morgan \& Elson reaction and which reached its maximum concentration at a time when reaction with Ehrlich's reagent had almost ceased. The stability of the newly-formed substance during prolonged incubation varied. The maximum amount detected corresponded to about $5 \%$ of the maximum amount of $N$-acetylhexosamine expected (using $N$-acetylglucosamine as standard) if de-aldolization were the only pathway of degradation of $N$-ANA in the organism. Further interpretation of the data must await the isolation and identification of this substance.

We would like to thank our colleague Dr A. Gottschalk for several discussions. The work was aided by a grant from the National Health and Medical Research Council, Canberra, A.C.T., Australia.

\section{REFERENCES}

Ada, G. L. \& French, E. L. (1950). Purification of the receptor destroying enzyme of $V$. cholerae. Aust. J. Sci. 13, 82.

ADA, G. L. \& French, E. L. (1957). Stimulation of the production of the receptor destroying enzyme (RDE) of $V$. cholerae by neuraminic acid derivatives. Aust. J. Sci. 19, 227.

Bacon, J. S. D. \& Edelman, J. (1951). The carbohydrates of the Jerusalem artichoke and other Compositae. Biochem. J. 48, 114.

Breuer, R. (1898). Uber das freie Chitosamin. Ber. dtsch. chem. Ges. 31, 2193.

Burnet, F. M., McCrea, J. F. \& Stone, J. D. (1946). Modification of human red cells by virus action. 1 . The receptor gradient for virus action in human red cells. Brit. J. exp. Path. 27, 228.

Burnet, F. M. \& Stone, J. D. (1947). The receptor destroying enzyme of $V$. cholerae. Aust. J. exp. Biol. med. Sci. 25, 227.

Feldoman, W. (1958). Production of receptor destroying enzyme by Vibrio comma in synthetic medium. J. Bact. 75, 26.

Finkelstein, R. A. \& LANKFoRd, C. E. (1955). Nutrient requirements of Vibrio cholerae. Bact. Proc. p. 49.

GotrschalK, A. (1955). 2-Carboxypyrrole: its preparation from and its precursor in mucoproteins. Biochem. J. 61, 298.

Gotrschalk, A. (1956). Neuraminic acid: the functional group of some biologically active mucoproteins. Yale J. Biol. Med. 28, 525.

Gotrschalk, A. (1957). Neuraminidase: the specific enzyme of influenza virus and Vibrio cholerae. Biochim. biophys. Acta, 23, 645.

Gottschalk, A. \& Graham, E. R. B. (1958). A neuraminidase susceptible disaccharide from bovine salivary mucoprotein. Z. Naturf. $13 b, 821$.

Gotrschalk, A. \& Lind, P. E. (1949). Product of interaction between influenza virus enzyme and ovomucin. Nature, Lond. 164, 232.

Hermer, R. \& Meyer, K. (1956). Studies on sialic acid of submaxillary mucoid. Proc. nat. Acad. Sci., Wash. $42,728$.

ISAACS, A. \& EDNEY, M. (1950). Variation in laboratory stocks of influenza viruses: genetic aspects of the variations. Brit. J. exp. Path. 31, 209.

KUHN, R. \& BROSSMER, R. (1956). Úber $O$-acetyl-lactaminsäure-lactose aus Kuhcolostrum und ihre Spaltbarkeit durch Influenza-virus. Ber. dtsch. chem. Ges. 89, 2013.

McCrea, J. F. (1947). Modification of red cell agglutinability by $\mathrm{Cl}$. welchii toxins. Aust. J. exp. Biol. med. Sci. 25, 127. 
Morgan, W. T. J. \& Elson, L. A. (1934). A colorimetric method for the determination of $N$-acetylglucosamine and $N$-acetylchondrosamine. Biochem. J. 28, 988.

Partridge, S. M. (1949). Aniline hydrogen phthallate as a spraying reagent for chromatography of sugars. Nature, Lond. 164, 443.

Reissig, J. L., Strominger, J. L. \& Leloir, L. F. (1955). A modified colorimetric method for the estimation of $\mathrm{N}$-acetylamino sugars. J.biol. Chem. 217, 959 .

WERNER, I. \& ODIN, L. (1952). On the presence of sialic acid in certain glycoproteins and in gangliosides. Acta Soc. Med. upsalien. 57, 230.

(Received 24 April 1959) 